\title{
Anticancer activity of a novel quinazolinone-chalcone derivative through cell cycle arrest in pancreatic cancer cell line
}

\author{
Zahoor A. Wani ${ }^{1}$, Anup S. Pathania ${ }^{1}$, Girish Mahajan ${ }^{1}$, Akanksha Behl ${ }^{1}$, Mubashir J. Mintoo ${ }^{1}$, \\ Santosh K. Guru' ${ }^{1}$, A. Viswanath ${ }^{2}$, Fayaz Malik ${ }^{1,3}$, Ahmed Kamal ${ }^{2}$, Dilip M. Mondhe ${ }^{1,3}$ \\ 1. Cancer Pharmacology Division, CSIR-I ndian Institute of I ntegrative Medicine, Jammu, India. 2. CSIR-I ndian Institute of \\ Chemical Technology, Tarnaka, Hyderabad, India. 3. Academy of Scientific and Innovative Research (AcSIR), Anusandhan \\ Bhawan, New Delhi, India.
}

Correspondence: Dilip M. Mondhe. Address: Cancer Pharmacology Division, CSIR-Indian Institute of Integrative Medicine, Jammu 180001, India. Email: dmmondhe@iiim.ac.in

Received: February 8, 2015

Accepted: March 22, 2015

Online Published: June 10, 2015

DOI : $10.5430 /$ jst.v5n2p73

URL: http://dx.doi.org/10.5430/jst.v5n2p73

\section{Abstract}

Background: Genotoxic effects of many of clinically useful anticancer drugs are due to their interaction with the amino groups of nucleic acids. Literature reveals that the chalcones however may be devoid of this important side effect. With this view in mind, we synthesized a novel quinazolinone-chalcone derivative and evaluated its anticancer potential.

Methods: Anticancer potential of A novel quinazolinone-chalcone derivative 2-Methyl-3-(3-((E)-3-(3,4,5-trimethoxyphenyl)-2-propenoyl)phenyl)-3,4-dihydro-4-quinazolinone (8b) was determined through MTT assay, colony formation assay, Wound healing assay, Cell cycle and Western Blot Analysis in Mia paca-2 cells treated with 8b.

Results: The cytotoxicity studies showed a concentration dependent decrease in cell viability of HCT-116, HL-60, PC-3, A-549, Mia pacca-2 and MCF-7 cell lines with $\mathrm{IC}_{50}$ values ranging from 5.5 to $8.5 \mu \mathrm{M}$. The motility of Mia paca-2 cells treated with $8 \mathrm{~b}$ was found inhibited in a dose dependent manner. Cell cycle studies revealed a concentration dependent rise in $\mathrm{G} 2 / \mathrm{M}$ phase of cell cycle from $1 \%$ to $52 \%$. Decreased expression of cyclins regulating $\mathrm{G} 2 / \mathrm{M}$ transition of the cell cycle (cyclin B1 and cdk1) was recorded after treatment of Mia Paca-2 cells with 8b. Mitochondrial membrane potential was also significantly lost in cultures exposed to $8 \mathrm{~b}$. However, nuclear morphology of $8 \mathrm{~b}$ treated Mia paca-2 cells revealed no significant changes. 8b significantly inhibited the growth of Ehrlich ascites carcinoma, Sarcoma-180 (ascites), Ehrlich tumor (solid) and Sarcoma-180 (solid).

Conclusion: The findings are indicative of $8 \mathrm{~b}$ exerting anticancer activity through cell cycle arrest at G2/M phase and not through apoptosis. Reduction in the motility of Mia paca- 2 cells indicates anti-metastatic potential of $8 \mathrm{~b}$.

\section{Key words}

Quinazolinone-chalcone, Cell cycle, Ehrlich tumor, Sarcoma-180, Metastasis

\section{I ntroduction}

Natural products constitute a major source of biologically active compounds that may serve themselves as significantly commercial entities or as lead structure providers for the development of modified derivatives with enhanced activity 
and/or reduced toxicity. In almost all therapeutic areas, many natural products and synthetically modified natural product derivatives have been developed for clinical use in order to treat human diseases ${ }^{[1]}$. During the past decade, the focus of drug development has been on the natural products and their synthetic and semi-synthetic analogs because of their least side effects. In the area of anticancer drug discovery, many natural products including chalcones are being studied by both the academia and the industry. However, only a few studies report in-depth mechanistic basis of their anti-proliferative activity.

Chalcones belong to the largest class of plant secondary metabolites and are synthesized in a large number of plant species. Chemically, they are aromatic ketones with two phenyl rings that are also intermediates in the synthesis of many biological compounds. They are considered to be precursors of flavonoids and isoflavonoids which serve in plant defense mechanisms to counteract reactive oxygen species (free radicals) and prevent molecular damage and damage by microorganisms, insects and animals. Chalcones possess multifarious biological activities like anti-inflammatory ${ }^{[2]}$, antioxidant ${ }^{[3]}$, antimicrobial ${ }^{[4]}$, anti-HIV ${ }^{[5]}$, anti-malarial ${ }^{[6]}$, anti-allergic ${ }^{[7]}$ and anticancer ${ }^{[8]}$. Owing to their easy synthesis and good safety profile, chalcones are being explored worldwide for their pharmacological activities.

Chalcones and their derivatives are reported to exhibit promising anticancer activity. This has inspired numerous synthetic efforts to develop novel synthetic chalcones. Many studies have demonstrated their anticancer activity against various tumor cells. Strong antiproliferative effects of natural and synthetic chalcones have been shown in both primary and established ovarian cancer cells and in gastric cancer HGC-27 cells ${ }^{[9]}$. Kinases like epidermal growth factor receptor and vascular endothelial growth factor receptor that are essential for the proliferation of tumor cells have also been reported to

be inhibited by chalcones ${ }^{[10,11]}$. Compounds containing $2(1 \mathrm{H})$-quinazolinone ring structure have also shown anticancer activities ${ }^{[12]}$. Further, chalcones are likely to be devoid of the genotoxic side effect ${ }^{[13-15]}$ which a number of anticancer drugs have due to their interactions with the amino groups of nucleic acids. Therefore, with the view of making good use of quinazolinones and chalcones, we synthesized a novel quinazolinone-chalcone derivative and evaluated its anticancer potential.

\section{Materials and methods}

\subsection{Chemicals and antibodies}

MEM, RPMI-1640, MTT (3-(4,5-dimethylthiazole-2-yl)-2,5 diphenyltetrazolium bromide), Rh-123(Rhodamine-123), penicillin, streptomycin, pyruvic acid, L-glutamine, PMSF (phenylmethanesulfonyl fluoride), PI (Propidium iodide), DNAse free RNAse, Hoechst 33258, eukaryotic protease inhibitor cocktail, camptothecin and fetal bovine serum were purchased from Sigma-Aldrich Co., India. Anti-human antibodies to PARP-1(\#SC8007), $\beta$-Actin (\#SC-47778), goat anti-mouse IgG-HRP (\#SC2031) and goat anti-rabbit IgG-HRP (\#SC2301) were purchased from Santa Cruz Biotechnology (Santa Cruz, CA, USA). Electrophoresis reagents, protein estimation kit and protein markers were purchased from Bio-Rad Laboratories, USA. Hyper film and ECL Plus Western blotting detection kit were from Amersham Biosciences, UK.

\subsection{Synthesis of $\mathbf{8 b}$}

The starting material for quinaxolinone-chalcone derivative (8b) was antranilic acid (compound 1) as outlined in Figure 1. The first synthetic step involved the condensation of anthranilic acid with acetic anhydride to afford benzoxazinone (compound 2) in quantitative yield. Later, benzoxazinone (compound 2) was coupled to 3-amino acetophenone to provide the quinazolinone (compound 3). This quinazolinone (compound 3) was made to undergo condensation reaction with substituted benzaldehydes in presence of a base to afford the desired quinazolinone-chalcone $8 \mathrm{~b}$ in good yield.

Reactions were performed on silica gel glass plates containing 60 GF-254, and visualized on TLC by UV light or iodine indicator. Column chromatography was performed with Merck 60-120 mesh silica gel. 1H spectra were recorded on 
Bruker UXNMR/XWIN-NMR (300 MHz) instrument. Chemical shifts $(\delta)$ were reported in ppm downfield from internal TMS standard. ESI spectra were recorded on Micro mass, Quattro LC using ESI+ software with capillary voltage $3.98 \mathrm{kV}$ and ESI mode positive ion trap detector. High-resolution mass spectra (HRMS) were recorded on QSTAR XL Hybrid MS/MS mass spectrometer. Melting points were determined with an Electro thermal melting point apparatus, and are uncorrected.

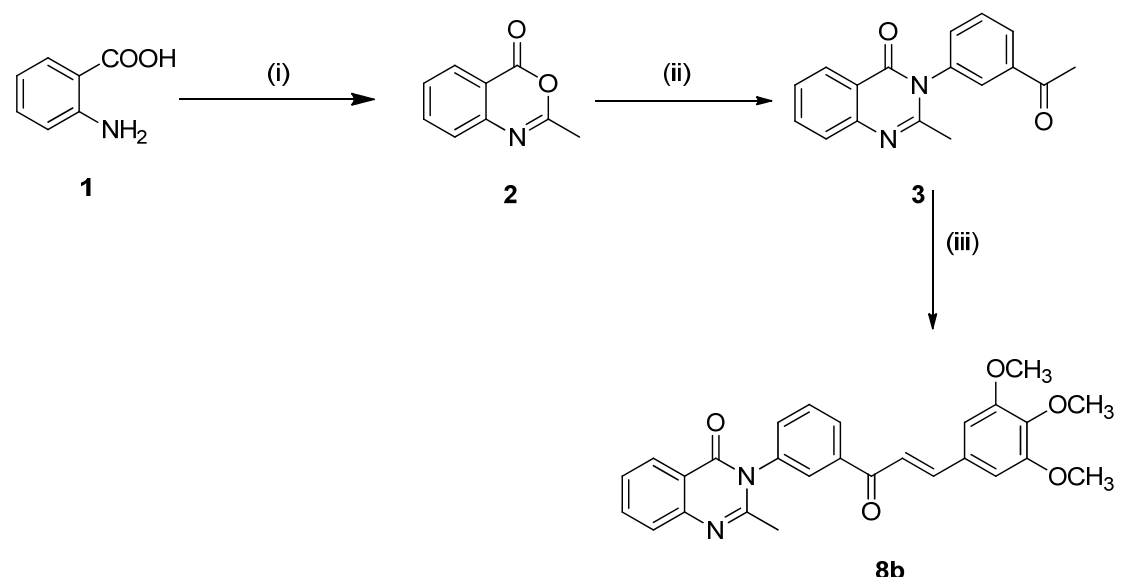

Figure 1. Reagents and conditions: (1) $\left(\mathrm{CH}_{3} \mathrm{CO}\right)_{2} \mathrm{O}, 150^{\circ} \mathrm{C}, 30 \mathrm{~min}$.; (2) 3-aminoacetophenone, $\mathrm{AcOH}$, reflux, $4 \mathrm{~h}$; (3) $\mathrm{Ba}(\mathrm{OH})_{2} \cdot \mathrm{H}_{2} \mathrm{O}, \mathrm{MeOH}, \mathrm{rt}, 12 \mathrm{~h}$.

\subsection{Synthesis of 2-methyl-4H-benzo[ 1,3$]$ oxazin-4-one (2)}

The compound 2 was prepared by heating $1(2.05 \mathrm{~g}, 15 \mathrm{mmol})$ in acetic anhydride $(5 \mathrm{ml})$ at $150^{\circ} \mathrm{C}$ for $30 \mathrm{~min}$. The reaction mixture was poured in ice water, filtered and the precipitate was washed with water, dried and used without purification to get 2 as white solid $(2.19 \mathrm{~g}, 91 \%) ; \mathrm{mp} 82-84^{\circ} \mathrm{C}$; $1 \mathrm{H} \mathrm{NMR}(\mathrm{CDCl} 3,300 \mathrm{MHz}): \delta 2.48(\mathrm{~s}, 3 \mathrm{H}), 7.49(\mathrm{~d}, 1 \mathrm{H}, \mathrm{J}=7.5 \mathrm{~Hz}), 7.55$ $(\mathrm{d}, 1 \mathrm{H}, \mathrm{J}=7.7 \mathrm{~Hz}), 7.77-7.84(\mathrm{~m}, 1 \mathrm{H}), 8.19(\mathrm{dd}, 1 \mathrm{H}, \mathrm{J}=1.1,7.9 \mathrm{~Hz}) ; \mathrm{MS}(\mathrm{ESI}): \mathrm{m} / \mathrm{z} 162(\mathrm{M}+\mathrm{H})+$.

\subsection{Synthesis of 3-(3-acetylphenyl)-2-methyl-3,4-dihydro-4- quinazolinone (3)}

The compound 3 was prepared by heating equimolar quantities $(1.61 \mathrm{~g}, 10 \mathrm{mmol})$ of 2 and 3 -amino acetophenone ( $1.35 \mathrm{~g}$, $10 \mathrm{mmol}$ ) in acetic acid at $120^{\circ} \mathrm{C}$ for $4 \mathrm{~h}$. The reaction mixture was then washed with cool sodium bicarbonate solution and then extracted with ethyl acetate $(2 \times 50 \mathrm{ml})$. The combined organic fractions were washed with water followed by brine, dried over $\mathrm{Na}_{2} \mathrm{SO}_{4}$ and purified by column chromatography (30\% ethyl acetate-hexane) to afford the compound 3 as white solid (2.36 g, 85\%); 1H NMR (CDCl3, $400 \mathrm{MHz}): \delta 2.25$ (s, 3H), $2.63(\mathrm{~s}, 3 \mathrm{H}), 7.47-7.51(\mathrm{~m}, 2 \mathrm{H}), 7.69(\mathrm{~d}, 1 \mathrm{H}, \mathrm{J}=5.8 \mathrm{~Hz})$, 7.77-7.81 (m, 1H), $7.89(\mathrm{t}, 1 \mathrm{H}, \mathrm{J}=2.2 \mathrm{~Hz}), 7.92(\mathrm{~d}, 1 \mathrm{H}, \mathrm{J}=8.0 \mathrm{~Hz}), 8.08(\mathrm{~d}, 1 \mathrm{H}, \mathrm{J}=8.0 \mathrm{~Hz}), 8.25(\mathrm{dd}, 1 \mathrm{H}, \mathrm{J}=1.4,8.0 \mathrm{~Hz})$; MS (ESI): $\mathrm{m} / \mathrm{z} 279(\mathrm{M}+\mathrm{H})+$.

\subsection{Synthesis of 2-Methyl-3-(3-( (E)-3-(3,4,5-trimethoxyphenyl)-2- propenoyl) phenyl)-3,4-dihydro-4-quinazolinone (8b)}

To a stirred solution of an equivalent amount of $3(278 \mathrm{mg}, 1 \mathrm{mmol})$ and 3,4,5-trimethoxy benzaldehyde (196 $\mathrm{mg}$, $1 \mathrm{mmol})$, in methanol was added $\mathrm{Ba}(\mathrm{OH})_{2} \cdot \mathrm{H}_{2} \mathrm{O}(568 \mathrm{mg}, 3 \mathrm{mmol})$ and stirred for $12 \mathrm{~h}$ at room temperature. After completion of the reaction as monitored by TLC, the solvent was evaporated, neutralized with dilute $\mathrm{HCl}$ and extracted with ethyl acetate $(2 \times 50 \mathrm{ml})$. The combined organic fractions were washed with water followed by brine, dried over $\mathrm{Na}_{2} \mathrm{SO}_{4}$ and purified by column chromatography ( $50 \%$ ethyl acetate-hexane) to afford the pure compound $8 \mathrm{~b}$ as yellow

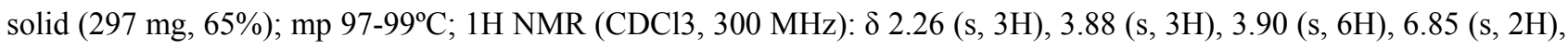
$7.34(\mathrm{~d}, 1 \mathrm{H}, \mathrm{J}=15.2 \mathrm{~Hz}), 7.47(\mathrm{~d}, 2 \mathrm{H}, \mathrm{J}=7.6 \mathrm{~Hz}), 7.69$ (t, 2H, J = 7.6 Hz), $7.75(\mathrm{~d}, 1 \mathrm{H}, \mathrm{J}=15.2 \mathrm{~Hz}), 7.78(\mathrm{t}, 1 \mathrm{H}, \mathrm{J}=$ 
$7.6 \mathrm{~Hz}), 7.90$ (s, 1H), 8.14 (d, 1H, J = 7.6 Hz), 8.24 (d, 1H, J = 7.6 Hz); 13C NMR (75 MHz, CDCl3) $\delta 24.45,56.42,61.01$, $106.08,119.46,120.56,121.77,122.24,123.12,124.20,126.92,127.23,129.51,130.68,133.09,138.48,142.77,144.38$, 147.39, 153.76, 162.35, 188.68; MS (ESI): m/z 457 (M+H)+.

\subsection{Cell culture}

Human cancer cell lines HL-60, A549, MCF-7, PC-3, HCT-116 and Mia Paca-2 were obtained from European Collection of Cell Cultures (ECACC), UK. RPMI/MEM containing 10\% FCS, 100U penicillin and $100 \mu \mathrm{g}$ streptomycin per ml of the medium was used for growing the cells. Cells were grown in a $\mathrm{CO}_{2}$ incubator (Thermocon Electron Corporation, Houston, TX) at $37^{\circ} \mathrm{C}$ with $95 \%$ humidity and $5 \% \mathrm{CO}_{2}$. Cells were treated with $8 \mathrm{~b}$ dissolved in DMSO while control cultures received only the vehicle (DMSO $<0.2 \%$ ).

\subsection{Cell proliferation assay}

Cells were seeded in 96 well plates and exposed to $8 \mathrm{~b}$ at concentrations ranging from $1 \mu \mathrm{M}$ to $100 \mu \mathrm{M}$ for $48 \mathrm{~h}$. MTT dye $(2.5 \mathrm{mg} / \mathrm{ml}$ in PBS) was added $4 \mathrm{~h}$ prior to the termination of experiment. The MTT-formazan crystals were dissolved in $150 \mu \mathrm{L}$ of DMSO and the OD was measured at $570 \mathrm{~nm}$ with reference wavelength of $620 \mathrm{~nm}^{[16]}$.

\subsection{Cellular and nuclear morphology}

Mia Paca-2 cells were treated with $8 \mathrm{~b}$ at 1, 3, 5 and $10 \mu \mathrm{M}$ concentrations for $24 \mathrm{~h}$. Cells were collected and washed with PBS and fixed in $400 \mu \mathrm{l}$ cold acetic acid: methanol $(1: 3, \mathrm{v} / \mathrm{v})$ overnight at $4^{\circ} \mathrm{C}$. Cells were washed with fixing solution and dispensed in $50 \mu \mathrm{l}$ of fixing solution. The cells were then spread on slide and dried overnight at room temperature. Hoechst $33,258(5 \mu \mathrm{g} / \mathrm{ml}$ in $0.01 \mathrm{M}$ citric acid and $0.45 \mathrm{M}$ disodium phosphate containing $0.05 \%$ Tween 20$)$ was added to stain the cells for $30 \mathrm{~min}$. PBS wash was given to the slides. Slides were covered with glass cover slips after pouring $40 \mu \mathrm{l}$ of mounting solution (PBS: glycerol, 1/1) and sealed with nail polish. Cells were observed under the microscope for nuclear morphological changes that occur in apoptosis ${ }^{[17]}$.

\subsection{DNA content and cell cycle phase distribution}

Mia Paca- 2 cells $\left(0.3 \times 10^{6} / \mathrm{ml} / 6\right.$ well culture plate) were treated with $1,3,5$ and $10 \mu \mathrm{M}$ concentrations of $8 \mathrm{~b}$ for $24 \mathrm{~h}$. Cells were collected, washed in PBS, fixed with $70 \%$ cold ethanol and placed at $4^{\circ} \mathrm{C}$ overnight. Again, PBS wash was given and cells were subjected to RNase digestion $(200 \mu \mathrm{g} / \mathrm{ml})$ at $37^{\circ} \mathrm{C}$ for $1.5 \mathrm{~h}$. Cells were then incubated with PI 206 (propidium iodide $10 \mu \mathrm{g} / \mathrm{ml}$ ) for $30 \mathrm{~min}$ and analyzed on flow cytometer FACS Calibur (Becton Dickinson, USA). The data were collected in list mode on 10,000 events and illustrated in a histogram, where the number of cells (counts) was plotted against the relative fluorescence intensity of PI (FL-2-A vs. FL2-W). Resulting DNA distributions were analyzed by Modfit software (Verity Software House Inc., Topsham, ME) for the proportions of cells in apoptosis, G1, S, and G2-M phases of the cell cycle ${ }^{[18]}$.

\subsection{Determination of mitochondrial membrane potential}

Mia Paca- 2 cells $\left(0.3 \times 10^{6} / \mathrm{ml}\right)$ were treated with different concentrations of $8 \mathrm{~b}(1,3,5$, and $10 \mu \mathrm{M})$ for $24 \mathrm{~h}$ and $\Lambda \Psi \mathrm{m}$ was measured by flow cytometry using Rhodamine-123 (Rh-123) dye. Rh-123 (1mM) was added $1 \mathrm{~h}$ before the termination of experiment. Cells were collected, washed in PBS and incubated with propidium iodide $(10 \mu \mathrm{g} / \mathrm{ml})$ for $15 \mathrm{~min}$. The decrease in the intensity of fluorescence because of the loss of mitochondrial membrane potential was analyzed in FL-1 channel ${ }^{[16]}$.

\subsection{Colony formation assay}

Mia Paca- 2 cells $\left(1 \times 10^{3}\right)$ were seeded in six well plate. After attachment of cells, fresh medium was added and treatment of $8 \mathrm{~b}$ at $1,3,5$ and $10 \mu \mathrm{M}$ concentrations was given. Cells were incubated at $37^{\circ} \mathrm{C}$ for 2 weeks and were fixed with $4 \%$ formaldehyde for $10 \mathrm{~min}$. Cells were thereafter incubated with $0.5 \%$ crystal violet for $30 \mathrm{~min}$. Images were taken by digital camera $^{[19]}$. 


\subsection{Wound healing assay}

Mia Paca-2 cells were seeded in six-well plate and maintained in DMEM. Scratches were given with a $200-\mu 1$ sterile tip. $8 \mathrm{~b}$ was added at different concentrations in fresh culture medium. Using an inverted microscope equipped with digital camera (Olympus Imaging Corp., Center Valley, PA, USA), the wound closure was photographed at 0, 24 and $36 \mathrm{~h}$ after injury.

\subsection{Preparation of whole cell lysates for immunoblotting}

Mia Paca-2 cells $\left(0.3 \times 10^{6} / \mathrm{ml}\right)$ after treatment with indicated concentrations of $8 \mathrm{~b}$ for $24 \mathrm{~h}$ were suspended in cold RIPA buffer (50 mM Tris-HCl, pH 7.4, 1\% Triton X-100, $150 \mathrm{mM} \mathrm{NaCl}, 30 \mathrm{mM} \mathrm{Na}_{2} \mathrm{HPO}_{4}, 5 \mathrm{mM}$ EDTA, 0.1\% SDS, $50 \mathrm{mM}$ $\mathrm{NaF}, 0.5 \mathrm{mM} \mathrm{NaVO}_{4}, 2 \mathrm{mM} \mathrm{PMSF}$, and $10 \%$ protease cocktail inhibitor) for $30 \mathrm{~min}$, vortexed and centrifuged at $12,000 \mathrm{~g}$ for $15 \mathrm{~min}$. Supernatant thus obtained was whole cell lysate which was stored at $-80^{\circ} \mathrm{C}$ for future use. Protein estimation was carried out employing BCA (Sigma assay) kit using BSA as standard and the absorbance was measured at $562 \mathrm{~nm}$ in plate reader (Biotek).

\subsection{Western blot analysis of various proteins}

Proteins from Mia Paca-2 cells treated with and without $8 \mathrm{~b}$ were resolved on SDS-PAGE at $100 \mathrm{~V}$ and transferred to polyvinylidenedifluoride (PVDF) membrane (Millipore) for $1.5 \mathrm{~h}$ at $250 \mathrm{~V}$ and $4^{\circ} \mathrm{C}$. Membrane was washed for 5 minutes by TBST and was probed with respective primary antibody for 2-3 $\mathrm{h}$. Membrane was again washed 5 times with TBST and each wash lasted for $5 \mathrm{~min}$. Anti- mouse secondary antibody was added for $1 \mathrm{~h}$ and enhanced chemiluminescence reagent (ECL kit, Amersham Biosciences) was used for the detection of protein bands.

\subsection{In vivo anticancer activity against ehrlich ascites carcinoma and ehrlich tumor (solid)}

$8 \mathrm{~b}$ was evaluated for its in vivo anti-cancer activity against various murine tumor models. Non-inbred Swiss albino mice (18-23 g) from an in-house colony, were maintained at $24 \pm 2^{\circ} \mathrm{C}$ temperature, 15-20 complete fresh air changes per hour and 50\%-60\% relative humidity. The animals were housed under standard husbandry conditions as per guide for the care and use of laboratory animals and fed with standard pellet diet (M/S Ashirwad Industries, Chandigarh, India) and autoclaved water was given ad libitum. Approval of the Institutional Animal Ethics Committee, Indian Institute of Integrative Medicine, Jammu was sought for the study and number of animals used in all the experiments.

Ehrlich Ascites Carcinoma (EAC) cells were obtained from the peritoneal cavity of Swiss albino mice harboring 8-10 days old ascitic tumor. $1 \times 10^{7}$ EAC cells were injected intra-peritoneally (i.p.) in Swiss Albino mice $(n=31)$ and the same number of these cells were injected intramuscularly in the right thigh of each animal of the other group $(\mathrm{n}=31)$ on day 0 .

Intraperitoneally injected animals were randomized the next day and assigned to different groups containing seven animals each in case of treatment groups and 10-15 animals in case of control group. First and second test groups received $25 \mathrm{mg} / \mathrm{kg}$ and $40 \mathrm{mg} / \mathrm{kg}$ of $8 \mathrm{~b}$ (i.p.) and the third group was treated with 5-FU which served as positive control. Tumor bearing control group was administered normal saline $(0.2 \mathrm{ml}$, i.p.). Treatment was given for nine consecutive days. For evaluation of tumor growth animals were sacrificed and ascitic fluid was collected from the peritoneal cavity of each mouse on day 12. Inhibition in tumor growth (percent) was calculated on the basis of the total number of tumor cells present in the peritoneal cavity as on day 12 of the experiment ${ }^{[20]}$.

Intramuscularly injected animals were also randomized on day 1 and divided into different groups containing seven animals each. However the control group contained 10 animals. First two groups received $30 \mathrm{mg} / \mathrm{kg}$ and $50 \mathrm{mg} / \mathrm{kg}$ of $8 \mathrm{~b}$ (i.p.) and the third group received 5-FU (22 $\mathrm{mg} / \mathrm{kg}$ i.p.) and the same served as positive control. Tumor bearing control group was given normal saline ( $0.2 \mathrm{ml}$ i.p.). Treatment lasted for nine consecutive days. Tumor dimensions were measured by means of vernier caliper on day 13. Inhibition in tumor growth in percentage was calculated on the basis of the weight 
of tumor present in the right thigh of animals. The average tumor weight of each group was calculated and the per cent tumor growth inhibition in treated groups was arrived at in comparison to control groups.

\subsection{I n vivo anticancer activity against Sarcoma-180 (ascites) and Sarcoma-180 (solid)}

Sarcoma-180 (Ascites) cells were obtained from the peritoneal cavity of BALB/c mice harboring 8-10 days old Sarcoma-180 (Ascites). $1 \times 10^{7} \mathrm{~S}-180$ cells were injected intra-peritoneally (i.p.) in $31 \mathrm{BALB} / \mathrm{c}$ mice and the same number of these cells were also injected intramuscularly in the right thigh of $24 \mathrm{BALB} / \mathrm{c}$ mice on day 0 . The procedure for experimentation was same as that of EAC and ET (solid).

Treatment of $8 \mathrm{~b}$ was given to two groups bearing Sarcoma-180 (Ascites) tumor at doses of $25 \mathrm{mg} / \mathrm{kg}$ and $40 \mathrm{mg} / \mathrm{kg}$ ( i.p.) for nine days and evaluation was done on $12^{\text {th }}$ day of the experiment.

Intramuscularly injected animals were assigned to three groups with seven animals each and the tumor bearing control group with ten animals. The first group was administered $30 \mathrm{mg} / \mathrm{kg}$ of $8 \mathrm{~b}$ ip. Rest of the procedure and experimentation was same as that of Ehrlich Tumor (solid). All the in vivo experiments were carried as per NCI protocols ${ }^{[20]}$.

\section{Results}

\subsection{8b inhibits proliferation of different cancer cell lines}

$8 \mathrm{~b}$ inhibited cell proliferation of various cancer cell lines. MTT assay was used to evaluate cell cytotoxicity. With increasing concentrations of 8b, a decrease in the viability of HCT-116, HL-60, PC-3, A-549, Mia pacca-2 and MCF-7 cell lines was observed. The IC50 values of $8 \mathrm{~b}$ against various cancer cell lines are shown in Figure 2B. As the compound showed most prominent activity against Mia Paca-2 cell line, further studies investigating the mechanism of cell death were carried out in Mia Paca-2 cells.

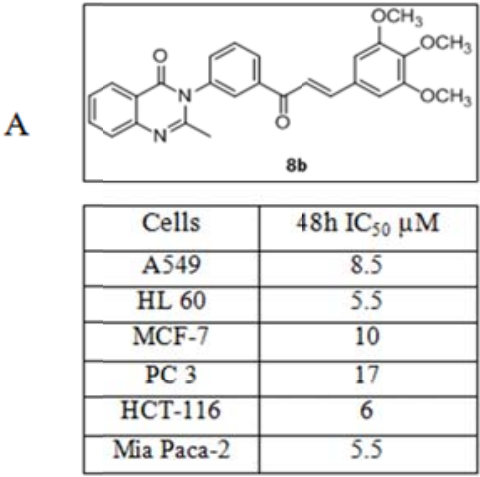

B

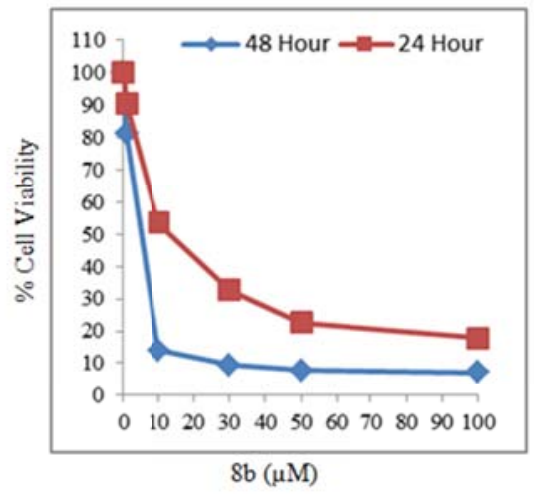

$\mathrm{C}$

Figure 2. (A) Chemical structure of the compound 8b. (B) Effect of $8 \mathrm{~b}$ on proliferation of various human cancer cell lines. (A549, HL-60, MCF-7, PC-3, HCT-116 and Mia Paca-2) The cells grown in 96-well culture plate were treated with 1, 10, 30, 50 and $100 \mu \mathrm{M}$ concentrations of compound $8 \mathrm{~b}$ for $44 \mathrm{~h}$. Thereafter cultures were incubated with MTT for another $4 \mathrm{~h}$ at $37^{\circ} \mathrm{C}$. Other conditions are described in Materials and Methods section. Data are Mean \pm SD (from three experiments). (C) Effect of compound $8 \mathrm{~b}$ for 24 and $48 \mathrm{~h}$ on Miapacca- 2 cells. Cells were treated with $8 \mathrm{~b}$ for 24 and $48 \mathrm{~h}$ at 1, 10, 30, 50 and $100 \mu \mathrm{M}$ concentrations. 


\section{2 $8 \mathrm{~b}$ induces no change in morphological features of cells}

With Hoechst staining, nuclear morphological changes can be monitored under fluorescence microscope as it selectively binds DNA. No significant changes were observed in the nuclear morphology of $8 \mathrm{~b}$ treated Mia paca-2 cells under fluorescent microscope (see Figure 3).

Control

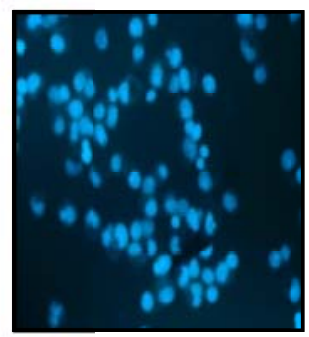

$8 \mathrm{~b}, 1 \mu \mathrm{M}$

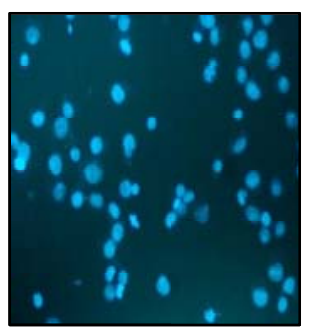

$8 \mathrm{~b}, 3 \mu \mathrm{M}$

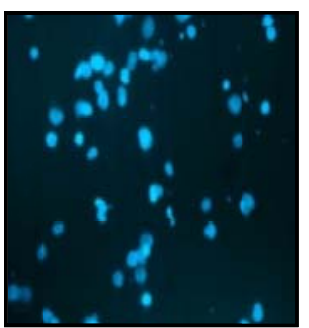

$8 \mathrm{~b}, 5 \mu \mathrm{M}$

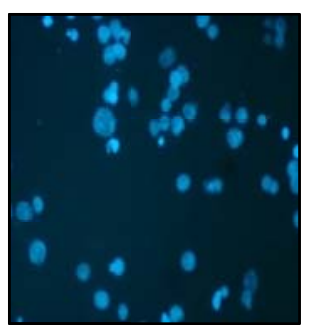

$8 \mathrm{~b}, 10 \mu \mathrm{M}$

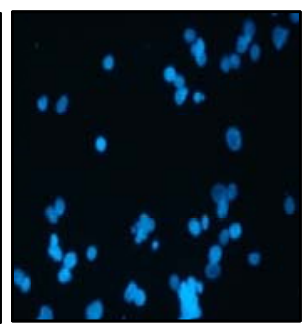

Figure 3. Effect of compound $8 \mathrm{~b}$ on the nuclear morphology of Miapacca- 2 cells. Cells were treated with $1,3,5$ and $10 \mu \mathrm{M}$ concentrations of $8 \mathrm{~b}$ for $24 \mathrm{~h}$ and subsequently stained with Hoechst 33258 as described in materials and methods section. Cells were observed under fluorescence microscope $(30 \times)$. Data are representative of one of three similarexperiments.

\subsection{Loss of mitochondrial membrane potential by $\mathbf{8 b}$}

Mia Paca-2 cells were analyzed by flow cytometer for Rh-123 uptake after their exposure to $8 \mathrm{~b}$ for $24 \mathrm{~h}$. Almost all of control cells were bio-energetically active and the same was revealed by high Rh-123 fluorescence. $8 \mathrm{~b}$ acted on mitochondrial functions very effectively in Mia Paca-2 cells as shown by a significant loss of mitochondrial membrane potential up to $49.3 \%$ in cells treated with $10 \mu \mathrm{M}$ concentration of $8 \mathrm{~b}$ (see Figure 4 ).

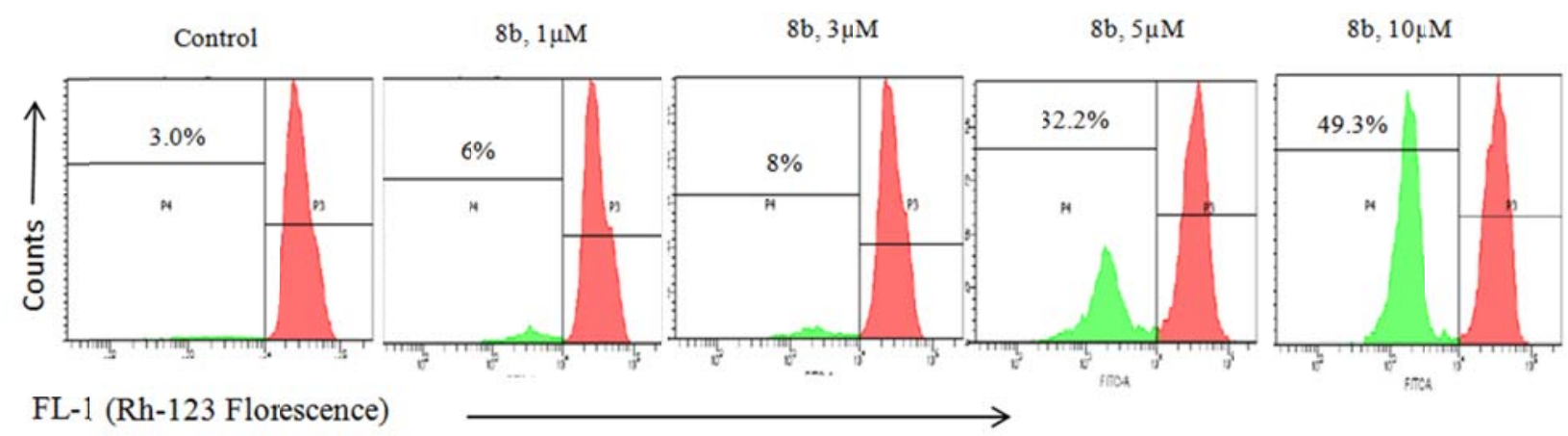

Figure 4. Compound $8 \mathrm{~b}$ induced loss of mitochondrial membrane potential $(\Psi \mathrm{mt})$ in Miapacca- 2 cells. Cells $(0.35 \times$ $10^{6} / \mathrm{ml} / 6$ well Culture plate) were incubated with indicated doses of $8 \mathrm{~b}$ for $24 \mathrm{~h}$. Thereafter, cells were stained with Rhodamine-123 (200 nM), added 40 min before experiment termination and analyzed in FL-1 channel of flow cytometer. Data are representative of one of three similar experiments.

\subsection{8b inhibits colony formation in Mia Paca-2 cells}

Single cell's ability to grow and form a colony is made use in colony formation assay. Upon treatment with $8 \mathrm{~b}$ at various concentrations, only a fraction of the seeded cells retained the capacity to produce colonies. A few colonies were found at $1 \mu \mathrm{M}$ concentration of $8 \mathrm{~b}$ but at higher concentrations colony formation almost disappeared (see Figure 5). 
Figure 5. Compound 8b inhibited colony formation in Mia Paca-2 cells. Cells were treated with different concentrations of $8 \mathrm{~b}$ for two weeks as described in materials and methods.
Control

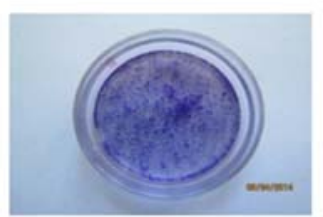

$8 \mathrm{~b}, 3 \mu \mathrm{M}$

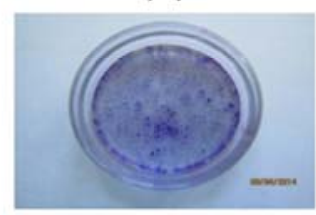

$8 \mathrm{~b}, 10 \mu \mathrm{M}$

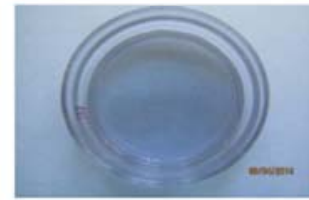

$8 \mathrm{~b}, 1 \mu \mathrm{M}$

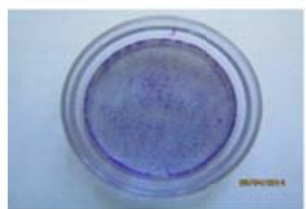

$8 \mathrm{~b}, 5 \mu \mathrm{M}$

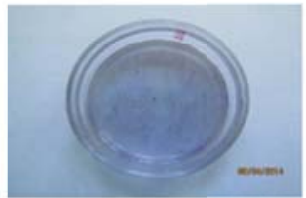

\subsection{8b prolongs wound healing in Mia paca- 2 cells}

Wound healing assay was used to determine whether $8 \mathrm{~b}$ could inhibit the motility of Mia paca-2 cells. In this assay, a wound was introduced in a cell monolayer by a sterile pipette tip. Cells were grown for $24 \mathrm{~h}$ after introduction of wound. In the untreated control, cells almost filled the scratch region; whereas the cells treated with $8 \mathrm{~b}$ inhibited motility of Mia paca-2 cells in dose dependent manner (see Figure 6).

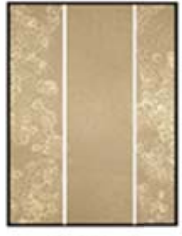

Control
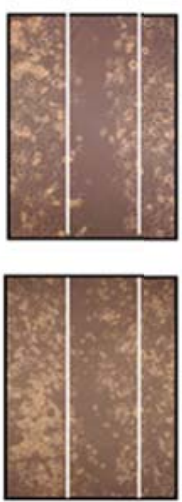

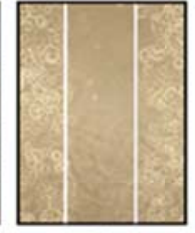

$1 \mu \mathrm{M}$
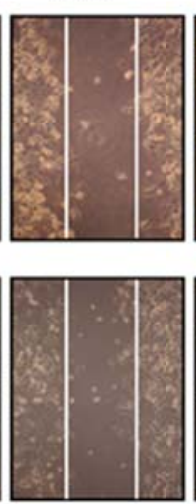

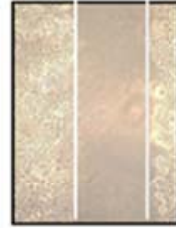

$3 \mu \mathrm{M}$
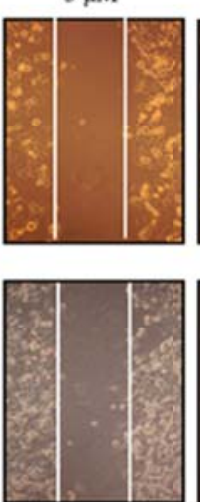
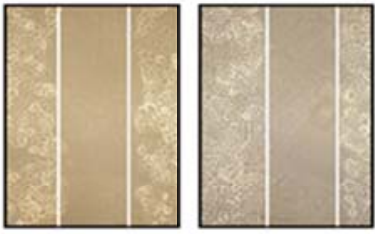

$10 \mu \mathrm{M}$
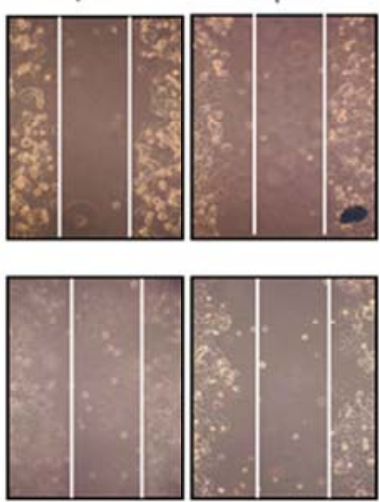

24 hour

0 hour

36 hour

Figure 6. Compound 8b inhibited migration in Mia Paca-2 cells. A scratch was given to the cells by sterile tip after attachment of cells in six well plate as described in materials and methods. 


\subsection{8b induces G2/ M phase cell cycle arrest}

Cell cycle distribution was analyzed to see the mechanism of action responsible for $8 \mathrm{~b}$ mediated cell growth inhibition. By measuring DNA content, apoptotic cells and cell cycle phase specificity can be identified. 8b produced a concentration dependent rise in $\mathrm{G} 2 / \mathrm{M}$ cell cycle phase. There was a rise in $\mathrm{G} 2 / \mathrm{M}$ population from $1 \%$ to $52 \%$ (see Figure 7 ).

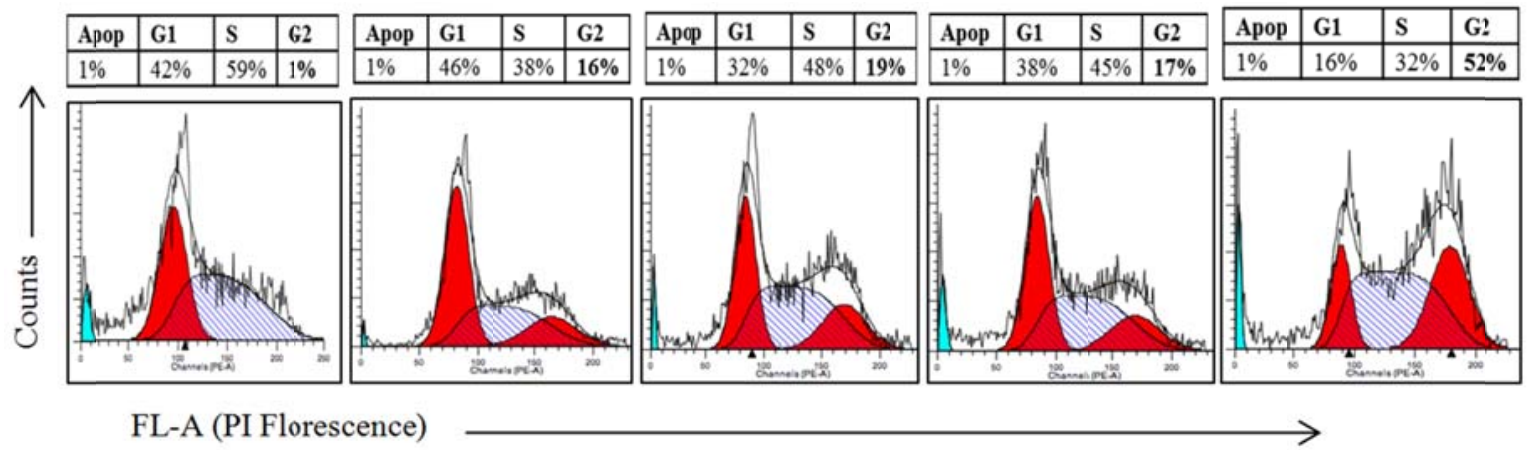

Figure 7. DNA cell cycle analysis of Miapacca-2 cells. Cells were treated with indicated concentrations of $8 \mathrm{~b}$ for $24 \mathrm{~h}$ and stained with propidium iodide $(10 \mu \mathrm{g} / \mathrm{ml})$ to determine DNA florescence and cell cycle phase distribution as described in materials and methods. Data were analyzed by Modfit software (Verity Software House Inc., Topsham, ME) for the proportions of different cell cycle phases. Data expressed are mean $\pm \mathrm{SD}$ of three independent experiments.

\subsection{Effect of $8 b$ on cell cycle regulatory proteins}

Treatment of Mia Paca-2 cells with $8 \mathrm{~b}$ caused decreased expression of cyclin B1 and cdk1. These cyclins regulate G2/M transition of the cell cycle (see Figure 8). There was no change in the expression of p53. Besides, no PARP-cleavage was seen.

Figure 8. Effect of compound $8 \mathrm{~b}$ on the expression of important proteins involved in the regulation of cell cycle. Mia Paca-2 cells were treated with 1-10 $\mu \mathrm{M}$ conc. of $8 \mathrm{~b}$ for $24 \mathrm{~h}$. Protein lysates were prepared and electrophoresed as described in materials and methods. $\beta$-actin was used as internal control. Data are representative of one of three similar experiments.

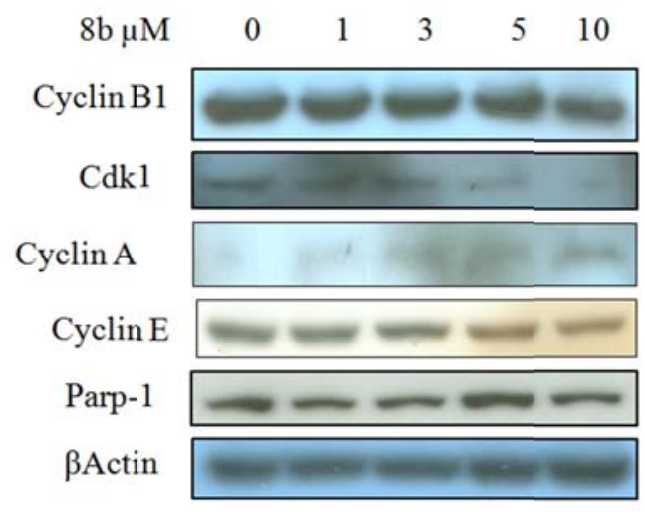

\subsection{8b inhibited tumor growth in experimental mice}

\subsubsection{Effect of 8b on Ehrlich Ascites Carcinoma and Ehrlich Tumor (solid)}

$8 \mathrm{~b}$ was evaluated for its efficacy of tumor growth inhibition in murine ascites and solid tumor models. $8 \mathrm{~b}$ at $25 \mathrm{mg} / \mathrm{kg}$ and $40 \mathrm{mg} / \mathrm{kg}$ intra-peritoneal doses for 9 consecutive days induced a significant tumor growth inhibition of $63.10 \%$ and 74.08\% respectively in Ehrlich Ascites Carcinoma, which was evidenced by a significant decrease in the volume of ascetic fluid, body weight and average number of tumor cells present in the ascitic fluid (see Table 1). Similarly, $8 \mathrm{~b}$ showed 37.30 and $54.01 \%$ inhibition in tumor growth at doses of 30 and $50 \mathrm{mg} / \mathrm{kg}$ body weight respectively, against Ehrlich Tumor (solid) (see Table 2). 
Table 1. In vivo anticancer activity of $8 \mathrm{~b}$ against Ehrlich Ascites Carcinoma (EAC)

\begin{tabular}{llllll}
\hline Sample & Dose(mg/kg i.p.) & $\begin{array}{l}\text { Tumor volume }(\mathbf{m l}) \\
\text { Mean } \pm \text { S.E }\end{array}$ & $\begin{array}{l}\text { Tumor weight }(\mathbf{g m}) \\
\text { Mean } \pm \text { S.E }\end{array}$ & $\begin{array}{l}\text { Tumor Cell count }\left(\times \mathbf{1 0}^{\mathbf{7}}\right) \\
\text { Mean } \pm \text { S.E }\end{array}$ & $\begin{array}{l}\text { \% Tumor growth } \\
\text { inhibition }\end{array}$ \\
\hline \multirow{2}{*}{$8 \mathrm{~b}$} & $25 \mathrm{mg} / \mathrm{kg}$ & $7.34 \pm 1.33$ & $7.32 \pm 1.35$ & $140.13 \pm 25.56^{* *}$ & 63.10 \\
& $40 \mathrm{mg} / \mathrm{kg}$ & $8.2 \pm 1.71$ & $8.07 \pm 1.68$ & $98.41 \pm 26.38^{* *}$ & 74.08 \\
$5 \mathrm{FU}$ & $20 \mathrm{mg} / \mathrm{kg}$ & $0.13 \pm 0.01^{* *}$ & $0.12 \pm 0.01^{* *}$ & $10.85 \pm 1.01^{* *}$ & 97.14 \\
Control & $\mathrm{NS}(0.2 \mathrm{ml})$ & $8.33 \pm 0.82$ & $8.14 \pm 0.87$ & $379.78 \pm 48.45$ & - \\
\hline
\end{tabular}

$* *$ highly significant $(p \leq .01)$. Data are Mean \pm S.E

Table 2. In vivo anticancer activity of $8 \mathrm{~b}$ against Ehrlich Tumor (solid)

\begin{tabular}{llll}
\hline Samples & Dose(mg/kg i.p.) & $\begin{array}{l}\text { Day 13 Tumor Weight (mg) } \\
\text { Mean } \pm \text { S.E }\end{array}$ & \% Tumor growth inhibition \\
\hline 8b & 30 & $795.05 \pm 94.39^{*}$ & 37.30 \\
& 50 & $583.1 \pm 83.82^{* *}$ & 54.01 \\
$5 \mathrm{FU}$ & 22 & $453.5 \pm 84.02^{* *}$ & 64.23 \\
Control & $\mathrm{NS}(0.2 \mathrm{ml})$ & $1268.1 \pm 14.96$ & - \\
\hline
\end{tabular}

$*$ significant $(p \leq .05) . * *$ highly significant $(p \leq .01)$. Data are Mean \pm S.E

\subsubsection{Effect of 8b on Sarcoma-180 (Ascites) and Sarcoma-180(solid)}

$8 \mathrm{~b}$ showed 70.12 and $78.32 \%$ tumor growth inhibition at doses of $25 \mathrm{mg} / \mathrm{kg}$ and $40 \mathrm{mg} / \mathrm{kg}$ respectively against Sarcoma180 Ascites (see Table 3), whilst against sarcoma-180 (solid) 8b showed a tumor growth inhibition of 54.98\% at a dose of $30 \mathrm{mg} / \mathrm{kg}$ body weight administered intraperitoneally for 9 consecutive days (see Table 4).

Table 3. In vivo anticancer activity of $8 \mathrm{~b}$ against Sarcoma-180 (Ascites)

\begin{tabular}{llllll}
\hline Sample & Dose $(\mathbf{m g} / \mathbf{k g}$ i.p.) & $\begin{array}{l}\text { Tumor volume }(\mathbf{m l}) \\
\text { Mean } \pm \text { S.E }\end{array}$ & $\begin{array}{l}\text { Tumor weight (gm) } \\
\text { Mean } \pm \text { S.E }\end{array}$ & $\begin{array}{l}\text { Tumor Cell count }\left(\times \mathbf{1 0}^{\mathbf{7}}\right) \\
\text { Mean } \pm \text { S.E }\end{array}$ & $\begin{array}{l}\text { \% Tumor growth } \\
\text { inhibition }\end{array}$ \\
\hline \multirow{2}{*}{$\mathrm{b}$} & $25 \mathrm{mg} / \mathrm{kg}$ & $2.87 \pm 0.60^{* *}$ & $2.75 \pm 0.68^{* *}$ & $36.41 \pm 11.56^{* *}$ & 70.12 \\
& $40 \mathrm{mg} / \mathrm{kg}$ & $2.32 \pm 0.60^{* *}$ & $2.27 \pm 0.51^{* *}$ & $26.42 \pm 10.13^{* *}$ & 78.32 \\
$5 \mathrm{FU}$ & $20 \mathrm{mg} / \mathrm{kg}$ & $0.17 \pm 0.01^{* *}$ & $0.15 \pm 0.007^{* *}$ & $5.57 \pm 0.42^{* *}$ & 95.42 \\
Control & $\mathrm{NS}(0.2 \mathrm{ml})$ & $7.71 \pm 0.68$ & $7.49 \pm 0.64$ & $121.87 \pm 11.02$ & - \\
\hline
\end{tabular}

** highly significant $(p \leq .01)$. Data are Mean \pm S.E

Table 4. In vivo anticancer activity of $8 \mathrm{~b}$ against Sarcoma-180 (solid)

\begin{tabular}{llll}
\hline Sample & $\begin{array}{l}\text { Dose } \\
\text { (mg/kg i.p.) }\end{array}$ & $\begin{array}{l}\text { Day 13 Tumor Weight (mg) } \\
\text { Mean } \pm \text { S.E }\end{array}$ & \% Tumor growth inhibition \\
\hline $8 \mathrm{~b}$ & 30 & $561.1 \pm 37.11^{* *}$ & 54.98 \\
$5 \mathrm{FU}$ & 22 & $391.6 \pm 28.28^{* *}$ & 68.58 \\
Control & $\mathrm{NS}(0.2 \mathrm{ml})$ & $1246.59 \pm 42.15$ & - \\
\hline
\end{tabular}

** highly significant $(p \leq .01)$. Data are Mean \pm S.E

Interestingly, treatment with $8 \mathrm{~b}$ at all doses and in all four murine tumor models was non- toxic to animals as none of the animals $(0 / 7)$ died during the experimental process. Besides, average body weight of all treated animals increased during the course of treatment (data not shown). 


\section{Discussion}

The major challenges associated with currently available anticancer agents include lack of selectivity, toxicity, resistance and development of secondary malignancy. These drawbacks have motivated the search for newer, more efficacious and better tolerated antitumor drugs, with natural products especially plants offering an inexhaustible reservoir for new drug discovery and development. Chalcones are widely present in edible plants. Chalcones and their derivatives are reported to exhibit promising anticancer activity. Therefore we tried to explore the anticancer activity of a novel chalcone derivative $8 b$.

The cytotoxic effect of $8 \mathrm{~b}$ was explored using a panel of cancer cell lines of different human tissue origin and it inhibited the proliferation of cells with IC50 values ranging from 5.5 to $17 \mu \mathrm{M}$ (see Figure 2). The results thus depict a better cytotoxic profile of $8 \mathrm{~b}$. In vivo anticancer potential of $8 \mathrm{~b}$ was studied in four murine tumors viz., Ehrlich Ascites Carcinoma, Ehrlich Tumor (solid), Sarcoma-180 (Ascites) and Sarcoma-180 (solid). Compound 8b showed a significant tumor growth inhibition against all the four murine tumor models (see Tables 1-4). Interestingly, the compound was non-toxic to animals at all the doses as no mortality was recorded in any group besides an increase in body weight of all the treated animals during the course of treatment with $8 \mathrm{~b}$. Hoechst staining was carried out to see if any changes like chromatin condensation, nuclear morphology or shrinkage of cells are induced by $8 b$, but the results did not show any one of these changes (see Figure 3). However, $8 \mathrm{~b}$ induced G2/M phase arrest of cell cycle, with increase in the population of cells up to $52 \%$. There was no increase in apoptotic population of cells even at higher concentrations of $8 \mathrm{~b}$. The percentage of apoptotic cells remained constant (1\%) in untreated control as well as in all the treatments at all concentrations. Besides, there was no DNA fragmentation seen upon treatment with $8 \mathrm{~b}$ (data not shown), which clearly confirms that $8 \mathrm{~b}$ inhibits tumor cell growth both in vitro and in vivo through the arrest of cell cycle only and not because of apoptosis.

Cell migration plays a critical role in tumor cell invasion and metastasis ${ }^{[21]}$. Inhibition of cell migration and invasion is an important property for a chemotherapeutic agent other than having potential to cause specific cancer cell death. Molecules involved in the inhibition of cancer cell migration could be potential agents for anti-metastatic therapy. We found that $8 \mathrm{~b}$ inhibited wound healing and colony formation in Mia paca-2 cells significantly.

Cancer may be regarded as a disease of the cell cycle. Deregulation of the cell cycle is one of the most frequent alterations during tumor development. Cell cycle progression is induced by Cyclin-dependent kinases (CDKs) and their cyclin partners as they are the positive regulators or accelerators of cell cycle ${ }^{[22]}$. We examined the expression of various cell cycle proteins (CDKs and cyclins) and found that $8 \mathrm{~b}$ decreased the expression of cyclin B1 and cdk1 which revealed the arrest of cell cycle at G2/M phase, as these two proteins are the key regulators of G2/M phase of cell cycle (see Figure 8). Further, $8 \mathrm{~b}$ also caused loss of mitochondrial membrane potential which may be due to stress, as cancer cells come under stress upon chemotherapy treatment.

One of the imidazo[2,1-b]pyridine/pyrimidine chalcone derivatives has been reported to induce apoptosis in MCF-7 cell line ${ }^{[23]}$ but it's in vivo efficacy has not yet been established. Recently, few halogenated chalcone derivatives have also been reported to possess in vitro cytotoxic activity against colon and ovarian cancer cell lines with IC50 values of 49.9 and $66.6 \mu \mathrm{M}$ respectively ${ }^{[24]}$. Among unconventional chalcones, 3-(3-chloro-2-(2,6-dinitro-4-(trifluoromethyl) phenoxy)phenyl)-1-p-tolylprop-2-en-1-one has been reported to be cytotoxic to MCF-7 cells with IC50 value of $0.03 \mu \mathrm{g} / \mathrm{ml}{ }^{[25]}$ and is found to inhibit tubulin polymerization. Thus, some of the chalcone derivatives are showing promise as anticancer agents but need further detailed studies with regards to their modes of action, in vivo efficacy and toxicities. In the light of the available literature, $8 \mathrm{~b}$ is a novel quinqzolinone-chalcone derivative and shows optimum anticancer activity both in vitro and in vivo by arresting cell cycle at G2/M phase.

Further studies on $8 \mathrm{~b}$ with respect to its efficacy against human cancer xenograft models and toxicity is undoubtedly necessary by the scientific and medical communities for its development as a future anticancer agent with intended clinical use for anti-metastatic therapy. 


\section{Conflict of interests}

Authors declare that there is no conflict of interests.

\section{Acknowledgements}

Senior author, Z. A. Wani gratefully acknowledges the financial support he received from the Council of Scientific and Industrial Research, New Delhi in the form of Senior Research Fellowship.

\section{References}

[1] Newman DJ, Cragg GM. Natural Products as Sources of New Drugs over the 30 Years from 1981 to 2010. J Nat Prod. 2012; 75(3): 311-35. PMid:22316239. http://dx.doi.org/10.1021/np200906s

[2] Wu J, Li J, Cai Y, et al. Evaluation and discovery of novel synthetic chalcone derivatives as anti-inflammatory agents. J Med Chem. 2011; 54(23): 8110-23. PMid:21988173. http://dx.doi.org/10.1021/jm200946h

[3] Nowakowska Z. A review of anti-infective and anti-inflammatory chalcones. Eur J Med Chem. 2007; 42(2): $125-37$. PMid:17112640. http://dx.doi.org/10.1016/j.ejmech.2006.09.019

[4] Chiaradia LD, Mascarello A, Purificação M, et al. Synthetic chalcones as efficient inhibitors of Mycobacterium tuberculosis protein tyrosine phosphatase PtpA. Bioorg Med Chem Lett. 2008; 18(23): 6227-30. PMid:18930396. http://dx.doi.org/10.1016/j.bmcl.2008.09.105

[5] Wu JH, Wang XH, Yi YH, et al. Anti-AIDS agents 54. A potent anti-HIV chalcone and flavonoids from genus Desmos. Bioorg Med Chem Lett. 2003; 13(10): 1813-5. http://dx.doi.org/10.1016/S0960-894X(03)00197-5

[6] Dominguez JN, Charris JE, Lobo G, et al. Synthesis of quinolinylchalcones and evaluation of their antimalarial activity. Eur J Med Chem. 2001; 36(6): 555-60. http://dx.doi.org/10.1016/S0223-5234(01)01245-4

[7] Dimmock JR, Elias DW, Beazely MA, et al. Bioactivities of chalcones. Curr Med Chem. 1999; 6(12): 1125-49. PMid:10519918.

[8] Srinivasan B, Johnson TE, Lad R, et al. Structure-activity relationship studies of chalcone leading to 3-hydroxy-4,3',4',5'tetramethoxychalcone and its analogues as potent nuclear factor $\mathrm{\kappa B}$ inhibitors and their anticancer activities. J Med Chem. 2009; 52(22): 7228-35. PMid:19883086. http://dx.doi.org/10.1021/jm901278z

[9] Shibata S. Anti-tumorigenic chalcones. Stem Cells. 1994; 12: 44-52. PMid:8142919. http://dx.doi.org/10.1002/stem.5530120109

[10] Yang EB, Guo YJ, Zhang K, et al. Inhibition of epidermal growth factor receptor tyrosine kinase by chalcone derivatives. Biochim Biophy Acta. 2001; 1550(2): 144-52. http://dx.doi.org/10.1016/s0167-4838(01)00276-x

[11] Rizvi SU, Siddiqui HL, Nisar M, et al. Discovery and molecular docking of quinolyl-thienylchalcones as anti-angiogenic agents targeting VEGFR-2 tyrosine kinase. Bioorg Med Chem Lett. 2012; 22(2): 942-4. PMid:22200597. http://dx.doi.org/10.1016/j.bmcl.2011.12.017

[12] Jampilek J, Musiol R, Finster J, et al. Investigating Biological Activity Spectrum for Novel Styrylquinazoline Analogues. Molecules. 2009; 14(10): 4246-4265. PMid:19924061. http://dx.doi.org/10.3390/molecules14104246

[13] Sabzevari O, Galati G, Moridani MY, et al. Molecular cytotoxic mechanisms of anticancer hydroxychalcones. ChemBiol Int. 2004; 148: 57-67. http://dx.doi.org/10.1016/j.cbi.2004.04.004

[14] Lee YS, Lim SS, Shin KH, et al. Anti-angiogenic and anti-tumor activities of 2'-hydroxy-4'-methoxychalcone. Biol Pharm Bull. 2006; 29: 1028. PMid:16651739. http://dx.doi.org/10.1248/bpb.29.1028

[15] Rozmer Z, Berki T, Perjési P. Different effects of two cyclic chalcone analogues on cell cycle of Jurkat T cells. ToxicolIn Vitro. 2006; 20: 1354. PMid:16828254. http://dx.doi.org/10.1016/j.tiv.2006.05.006

[16] Bhushan S, Singh J, Rao MJ, et al. A novel lignin composition from Cedrusdeodara induces apoptosis and early nitric oxide generation in human leukemia Molt-4 and HL-60 cells. Nitric Oxide. 2006; 14: 72-8. PMid:16288976. http://dx.doi.org/10.1016/j.niox.2005.09.009

[17] Saxena A, Saxena AK, Singh J, et al. Natural antioxidants synergistically enhance the anticancer potential of AP9-cd, a novel lignin composition from Cedrusdeodara in human leukemia HL-60 cells. Chem Biol Int. 2010; 188: 580-590.

[18] Bhushan S, Kumar A, Malik F, et al. A triterpenediol from Boswelliaserrata induces apoptosis through both the intrinsic and extrinsic apoptotic pathways in human leukemia HL-60 cells. Apoptosis. 2007; 12: 1911-1926. PMid:17636381. http://dx.doi.org/10.1007/s10495-007-0105-5

[19] Kumar S, Guru SK, Pathania AS, et al. Autophagy triggered by magnolol derivative negatively regulates angiogenesis. Cell Death Dis. 2013; 4. http://dx.doi.org/10.1038/cddis.2013.399 
[20] Geran RI, Greenberg NH, MacDonald MM, et al. Protocol for screening chemical agents and natural products against animal tumors and other biological systems. Cancer Chemother Rep. 1972; 3: 1-103.

[21] Yamaguchi H, Wyckoff J, Condeelis J. Cell migration in tumors. Cur Opin Cell Biol. 2005; 17(5): 559-64. PMid:16098726 http://dx.doi.org/10.1016/j.ceb.2005.08.002

[22] Park M, Lee S. Cell Cycle and Cancer. J Biochem Mol Biol. 2003; 36: 60-65. http://dx.doi.org/10.5483/BMBRep.2003.36.1.060

[23] Ahmed K, Reddy Surendranadha J, Janaki Ramaiah M, et al. Design, synthesis and biological evaluation of imidazopyridine/ pyrimidine-chalcone derivatives as potential anticancer agents. Med. Chem. Commun. 2010; 1: 355-360. http://dx.doi.org/10.1039/c0md00116c

[24] Jain Upendra K, Bhatia Richa K, YadavManmohan Singh, et al. Synthesis and biological evaluation of halogenated chalcone derivatives as potential anticancer agents. Int J Nat Prod Sci. 2012: Spl Issue 1; 121.

[25] Zhang H, Liu JJ, Sun J, et al. Design, synthesis and biological evaluation of novel chalcone derivatives as antitubulin agents. Bioorg Med Chem. 2012; 20(10): 3212-8. PMid:22503741 http://dx.doi.org/10.1016/j.bmc.2012.03.055 